14. Стандарт вищої освіти України. Перший (бакалаврський) рівень вищої освіти. Ступінь вищої освіти «бакалавр». Галузь знань 07 «Управління та адміністрування», спеціальність 073 «Менеджмент», затв. наказом МОНУ від 29.10.2018 № 1165. URL: https://mon.gov.ua/ storage/app/media/vishcha-osvita/ zatverdzeni\%20standarty/12/21/073-menedzhmentbakalavr.pdf (дата звернення: 08.04.2020).

15. Стандарт вищої освіти України. Другий (магістерський) рівень вищої освіти. Ступінь вищої освіти «магістр». Галузь знань 07 «Управління та адміністрування», спеціальність 073 «Менеджмент», затв. наказом МОНУ від 10.07.2019 № 959. URL: https://mon.gov.ua/storage/app/media/vishcha- osvita/zatverdzeni\%20standarty/2019/07/12/073-mene dzhment-magistr.pdf (дата звернення: 08.04.2020).

16. Університет «КРОК»: навчально-науковий Інститут магістерської підготовки та післядипломної освіти. URL: https://www.krok.edu.ua/ua/ navchalni-programi/ fpo/menedzhment (дата звернення: 08.04.2020).

17. LvBS та State University of New York poзpoбляють навчальну програму для медичних менеджерів / Львівська бізнес-школа УКУ. URL: https:// lvbs. com.ua/news/lvbs-ta-state-university-of-new-yorkrozroblyayut-navchalnu-programu-dlya-medichnihmenedzheriv/ (дата звернення: 08.04.2020).

Дата надходження до редакиї: 10.04.2020 p.
УДК 37.091.33

DOI: 10.37026/2520-6427-2020-102-2-137-140
Ірина УДОВИЧЕНКО,

доктор педагогічних наук, доиент, проректор із науково-педагогічної та методичної роботи Сумського ОІППО

\title{
МІЖПРЕДМЕТНІ ЗВ'ЯЗКИ ЗМІСТУ ПРОФІЛЬНОГО НАВЧАННЯ ГЕОГРАФІЇ УЧНІВ ЗАКЛАДІВ ЗАГАЛЬНОЇ СЕРЕДНЬОЇ ОСВІТИ
}

\begin{abstract}
У статті акцентовано увагу на значенні міжпредметних зв'язків у шкільному навчанні на сучасному етапі розвитку освіти, щзо обумовлено нинішнім рівнем розвитку науки та вимогами до ступеня освіченості випускників закладів загальної середньоі освіти, зокрема профільного спрямування. На основі міжпредметних зв'язків, використаних під час опанування учнями змісту географії на профільному рівні, подано приклади запитань, завдань та тем уроків інтегрованого спрямування.

Ключові слова: міжпредметні зв'язки, географія, навчання, профільне спрямування, заклади загальної середньої освіти.

В статье акцентировано внимание на значении межпредметных связей в школьном обучении на современном этапе развития образования, что обусловлено современным уровнем развития науки и требованиями к уровню образованности выпускников заведений общего среднего образования, особенно профильного направления. На основании межпредметных связей, использованных во время изучения учениками содержания географии на профильном уровне, предоставлено примеры вопрсов, заданий $и$ тем уроков интегрированого направления.

Ключевые слова: межпредметные связи, география, обучение, профильное направление, заведения общего среднего образования.
\end{abstract}

The current realities in the development of Ukrainian society have led to new priorities for the education sector, which also include in Ukraine, rethinking approaches to the building of a pedagogical process as a whole and using integrated, cross-curricular learning in particular.

The article attention is focused on the importance of intersubjective connections in school education at current stage of education reform, which is determined by the current level of development of science and requirements for the education level of school graduates.

The role of cross-curricular relationships in the development of personality traits that are formed under the influence of the educational functions of cross-curricular communication and students' knowledge, under the influence of the educational function of cross-curricular relationships; creativity and independence, under the influence of a developing function; complex perception of information - a constructive function is important.

An example, item, print job, example subject of mininotes of binary lesson of senior profile high school is presented.

The purpose of the article is to highlight the importance of integrating natural and humanities, in the lessons of geography and cross-curricular relations in the education of students in general secondary schools, including specialization.

The conducted research and practical experience make it possible to conclude that the use of binary lessons 
is one of the effective ways to increase students' interest in learning.

Ability to work at a cross-curricular level develops general educational skills and skills of students, provides them with the formation of a holistic system of ideas about the dialectical-materialistic laws of knowledge of the world in their interconnection and interdependence, and promotes a broader view and range of ideas.

Key words: cross-curricular, geography, education, profile level, graduates of general secondary education.

Постановка проблеми. Розвиток міжпредметних зв'язків у шкільному навчанні обумовлена сучасним рівнем розвитку науки та вимогами до ступеня освіченості випускників закладів загальної середньої освіти.

Інтеграція наукових знань висуває нові вимоги до вчителів як фахівців. Як наслідок - зростає роль знань людини в галузі, суміжній зі спеціальністю наук та натомість умінь комплексно застосовувати їх у вирішенні різних навчальних, методичних завдань.

Сучасному вчителеві потрібно не так подати значний обсяг інформації з теми, як навчити учнів осмислювати іiі, знаходити додаткові дані за допомогою міжпредметних зв'язків, а ще більше - уміти ними послуговуватися та використовувати на практиці. Зробити навчання цікавим, комплексним допомагають практико-орієнтований, інтегрований підходи, що дають змогу використати міжпредметні зв'язки, узагальнення 3 метою грунтовного опанування учнями навчального матеріалу.

Аналіз наукових досліджень і публікацій. Проблему міжпредметних зв'язків у своїх працях розглядали Я.-А. Коменський, Дж. Локк, К. Ушинський та ін., зауважуючи на необхідності взаємозв'язків між навчальними предметами для відображення цілісної картини природи та 3 метою створення системи знань і правильного світорозуміння учнями. Так, Я.-А. Коменський відстоював думку про взаємопов'язане вивчення граматики, філософії та літератури, а Дж. Локк - історії та географії [4].

Значення міжпредметних зв'язків у своїх дослідженнях обгрунтовували I. Звєрєв, В. Коротов, В. Максимова, М. Скаткін та ін. як необхідну умову єдності навчання та виховання, засіб комплексного підходу до предметної системи навчання. Зокрема, I. Звєрєв та В. Максимова міжпредметні зв'язки розглядали як дидактичний засіб, що передбачає комплексний підхід до формування й засвоєння учнями змісту освіти, який дає можливість здійснювати зв'язки між предметами для поглибленого, всебічного розгляду різних понять, процесів і явищ [5].

Питання класифікації міжпредметних зв'язків розглядали Р. Аббасова, В. Максимова, В. Рекуненко, М. Сорокіна, С. Тадиян, Н. Черкес-Заде та ін. [5].

Складові міжпредметних зв'язків досліджували Н. Антонов, Н. Лошкарьова та ін. Так, грунтуючись на філософському розумінні структури зв'язку між навчальними предметами та аналізуючи види зв'язків, Н. Антонов у понятті «міжпредметні зв'язки» виокремив три ознаки: склад, спосіб, спрямованість. Зокрема, за складом це - об'єкти, факти, поняття, теорії, методи; за способом - логічні, методичні прийоми й форми освітнього процесу, за допомогою яких реалізуються зв'язки в змісті; за спрямованістю формування загальних умінь і навичок, комплексне використання знань у процесі вирішення навчальних завдань. Натомість Н. Лошкарьова виділила зв'язки між предметами за змістом навчального матеріалу, формуванням умінь, використаними методами, запропонувавши класифікацію міжпредметних зв'язків iз двома «базисами»: знання та види діяльності [4].

Мета статті - розгляд питання значимості міжпредметних зв'язків у навчанні учнів закладів загальної середньої освіти, зокрема профільного спрямування, на сучасному етапі розвитку освіти.

Виклад основного матеріалу. Сучасні реалії в розвитку суспільства України обумовили нові пріоритетні завдання галузі освіти, які стосуються й переосмислення підходів до побудови педагогічного процесу загалом та використання комплексного, міжпредметного, інтегрованого навчання зокрема.

В Україні вперше комплексний підхід у навчанні почали впроваджувати на початку 20 років XX століття. Проте комплексні програми «фактично призводили до скасування самостійності та якісної своєрідності навчального предмета..., вивчення концентрувалося навколо комплексної проблеми». Тому на початку 30 років XX століття від такого підходу в освіті здебільшого відмовилися. Повернулися до розгляду цього питання вже у 70-80 роках XX століття, уживаючи здебільшого поняття «інтегрований підхід» замість «міжпредметні зв'язки» [3].

У новому Державному стандарті базової та повної загальної середньої освіти України наголошується на важливості міжпредметних зв'язків у формуванні системи знань учнів та уявлень ними історичного розвитку суспільства, цілісності процесів і явищ у світі, взаємодії суспільства та природи [2].

Важливим є питання ролі міжпредметних зв'язків у розвитку рис особистості, що формуються під впливом виховних функцій міжпредметних зв'язків та знань учнів (зокрема, освітньої функції міжпредметних зв'язків), творчості та самостійності (розвиваюча функція), комплексного сприйняття інформації (конструктивна функція).

3 огляду на те, що географічний глосарій повторюється в змісті інших навчальних предметів, наприклад, таких, як фізика, хімія, математика, біологія, накшталт, дотичних до понять: «повітря» (склад повітря, проблема чистого повітря, біологічна роль кисню, атмосферний тиск, шкала Цельсія, енергія та сила вітру та ін.), «вода» (склад води, поширення води в природі, роль води у житті людини, охорона води від забруднення, хвилі, енергія води, сила припливної хвилі та цунамі тощо) тощо, можливим є використання завдань, запитань інтегрованого спрямування.

В опануванні змісту географії, зокрема в контексті вимог нової української школи, доцільно використовувати запитання інтегрованого спрямування, як-от:

1) один із видів швидкісного гірськолижного спорту має шведську назву, що перекладається (зі шведської) як «слід на схилі»; укажіть назву цього спорту та де в України існують умови для його розвитку;

2) у невеличкому містечку на південному заході Франції вперше було виготовлено легку сітчасту тканину (від назви міста походить назва тканини), з якої тепер роблять гардини; укажіть назву міста і тканини, показавши на географічній карті найбільші гардино-тюлеві фабрики України.

Прикладами інтегрованих завдань, у процесі виконання яких поєднуються знання 3 інших навчальних предметів (фізика, хімія, біологія, математика, економіка, екологія, основи безпеки життєдіяльності) 
та використовуються міжпредметні зв'язки, можуть бути такі варіанти:

1) наведіть по одному прикладу фізичних, хімічних, біологічних, географічних прочесів (явищ), щзо відбуваються навколо нас $і$ супроводжуються: зміною кольору, зміною агрегатного стану речовини, виділенням енергії, та вкажіть такі прочеси (явища), що характерні для вашого регіону;

2) за допомогою математичних підрахунків запропонуйте енергозберігаючий варіант споживання електроенергї в домогосподарстві, закладі загальної середньої освіти, якщчо відомо, шчо в кімнаті 9 LED лампочок по 100 Вт кожна; у випадку, коли вони світяться марно 1 годину, втрачається 0,9 кBm / год електроенергії. Здійсніть обрахунки, якщчо відомо, шьо у школі (квартирі, будинку) 10 кімнат. Скільки витрачається електроенергї за 2 години марної роботи лампочок та скільки грошей потрібно заплатити, якшо 1 кBm/год коштуе 14,4 коп.? Назвіть вітчизняних товаровиробників із виготовлення LED ламп.

Однією із важливих форм реалізації міжпредметних зв'язків $є$ інтегровані, бінарні уроки, адже проведення таких уроків характеризується: інтегруванням змісту кількох (зазвичай двох) предметів в одній темі, проблемі; навчанням однієї теми групою (здебільшого із двох осіб) учителів за попередньо синхронізованим спільним календарно-тематичним і поурочним плануванням; застосуванням методів, форм, прийомів, технологій, спрямованих на комплексне подання й сприйняття навчального матеріалу; реалізацією навчання через досвід, отриманий учнями на іншому уроці та в повсякденному житті [4].

Використання бінарних, інтегрованих уроків географії з історією, правознавством, суспільствознавством, інформатикою, економікою, українською мовою та літературою, іноземними мовами тощо сприяє формуванню в учнів: цілісного уявлення про явища природи та взаємозв'язки між ними; знань й умінь, які вони можуть використовувати під час вивчення інших предметів; можливості застосовувати отримані знання на практиці в конкретних життєвих ситуаціях та $є$ прикладом використання міжпредметних зв'язків у навчанні географії.

Для прикладу розглянемо фрагмент бінарного уроку з фізико-економічної географії Укрїни та англійської мови в 11 класах на тему «Україна на політичній карті Європи і світу. Географічне положення України», метою проведення якого є формування в учнів уявлення про фізико-географічне положення України, сприяння розвиткові оцінки геополітичного положення країни та її місця в Європі (світі) засобами виховання громадянської компетентності.

Основними завданнями проведення такого уроку є:

- навчити учнів характеризувати поняття «фізико-географічне положення держави»;

- вивчити основні показники, за якими визначається фізико-географічне та геополітичне положення України;

- розглянути особливості географічного та геополітичного положення України на карті світу, Свропи;

- ознайомити учнів із головними позитивними та негативними ознаками геополітичного положення України;

- поглибити вміння учнів у монологічному, діалогічному мовленні та аудіюванні;

- розвивати навички роботи з географічною картою та просторове логічне мислення;
- виховувати ціннісне ставлення особистості до держави і суспільства, культуру спілкування, самоконтроль, самодисципліну.

На означеному уроці географії прикладом завдань, озвучених англійською мовою, можуть бути такі:

1) Learning new material (game "Is it true that...», the questions put by the teacher begin with the words "Is it true that...», the students respond unambiguously («yes» or «no»):

- Ukraine is a large European country;

- The area of Ukraine is 607000 square km;

- About $7 \%$ of Europe's population resides in Ukraine;

- Ukraine occupies the first place in Europe by area;

- In terms of population, Ukraine ranks approximately the10th in the world;

- Ukraine has access only to the Black Sea;

- Ukraine borders on only three European countries.

2) It is suggested to review the "panorama of business cards of the neighboring countries" (overview of "business cards» (pre-emptive task), conversation:

- Where is Ukraine located?

- What's its territory?

- What countries does Ukraine border on?

- Do you agree that Ukraine is a country of remarkable beauty?

- What are the main rivers in our country? What do rivers provide Ukraine with?

- What can you tell about the mountains on the territory of Ukraine?

- What is the country washed by?

- Could you name some big ports in Ukraine? What are they?

3) The task read the text and fill in the blanks:

Ukraine's area is 233,088 square miles. It's slightly larger than France. Ukraine mainly a vast plain with no natural except the Carpathian Mountains in the south-west the Black Sea in the south. Central southern Ukraine is primarily steppe, with fertile soils exceptionally suited for grain farming. In east there is the industrial heartland containing reserves of mineral deposits known as the Donbas or Donetsk Basin. Northern and western are hilly, forested areas with many picturesque resorts. There are two mountain ranges, the on its western border where winter sports very popular; and the Crimean range, which the Crimean peninsula. The Crimea is a destination not only for Ukrainian tourists, but for the people from eastern and western.

Подібний варіант вивчення навчального матеріалу $€$ прикладом використання міжпредметних зв'язків, що сприяє комплексному світосприйняттю учасниками освітнього процесу та спрямовується на формування компетентних випускників закладів освіти загалом та профільного спрямування зокрема, що сьогодні неабияк актуально.

Використання міжпредметних зв'язків, засобів компетентнісно орієнтованого навчання географії в закладах загальної середньої освіти в такий спосіб сприяє реалізації (окрім функцій організації освітнього процесу - навчальної, розвивальної, виховної) також дидактичної функції разом з інформаційно-пізнавальною, дослідницькою, самоосвітньою й методичною в поєднанні 3 інформаційною, інтегративною, корегувальною, відновлювальною, компенсаторною, моделювальною, діагностичною, прогностичною тощо, що загалом спрямовуються на організацію компетентнісно орієнтованого навчання учнів [1], зокрема на профільному рівні. 
3 огляду на зазначене вище вагомим чинником реалізації міжпредметних зв'язків у процесі навчання географії учнів закладів загальної середньої освіти $є$ бажання та здатність учителів добирати доцільні засоби навчання, адаптувати навчальний матеріал до життєвих потреб учнів, зробивши його практико-орієнтованим, особистісно значущим.

Швидкість оновлення інформації та урізноманітнення засобів ii передачі вимагає від учительсько-учнівського загалу мобільності щодо їі обробки, геопросторового світосприйняття, навичок роботи 3 різними джерелами знань, що натомість спрямовується на розвиток і формування географічної та мовної компетентностей учасників освітнього процесу.

Висновки. Проведені нами дослідження та практичний досвід дають змогу зробити висновок, що вміння працювати на міжпредметному рівні розвиває загальнонавчальні вміння та навички учнів, забезпечує формування в них цілісної системи уявлень про діалектико-матеріалістичні закони пізнання навколишнього світу в їх взаємозв'язку та взаємообумовленості, сприяє розширенню кругозору та діапазону уявлень про їхнє практичне застосування.

Значні можливості щодо реалізації міжпредметних зв'язків у навчанні закладені в змісті географії у школі за умов мобільності вчителів, наявності в них відповідних навичок роботи, мотивації щодо підвищення рівня практико-орієнтованого навчання учнів - майбутніх компетентних випускників закладів загальної середньої освіти.

Зважаючи на вищеозначене, перспективами наших подальших наукових розвідок $є$ вивчення особливостей навчання географії учнів закладів загальної середньої освіти засобами колективно-компетентнісної взаємодії.

\section{СПИСОК ВИКОРИСТАНОЇ ЛІТЕРАТУРИ}

1. Бібік Н. М. Компетентнісний підхід: рефлексивний аналіз застосування / Н. М. Бібік // Компетентнісний підхід у сучасній освіті: світовий досвід та українські перспективи. - К. : К.І.С., 2004. - С. 47-53.

2. Державні стандарти базової і повної середньої освіти // Урядовий кур'єр. - 2012. - № 19. - С. 5.

3. Компетентнісний підхід у сучасній освіті: світовий досвід та українські перспективи / О. В. Овчарук ; за заг. ред. О. В. Овчарук. - К. : К.І.С., 2004. 112 с. - (Серія «Бібліотека з освітньої політики»).

4. Рекуненко В. В. Методика проведення бінарних занять / В. В. Рекуненко. - К. : УМК із підготовки молодших спеціалістів, 1995. - 277 с.

5. Удовиченко I. В. Концептуальні засади змісту навчання географії учнів старшої школи на профільному рівні : [монографія] / І. В. Удовиченко. - К. : Педагогічна думка, 2018. - 360 с.

Дата надходження до редакиії: 09.04.2020 p. 